\title{
Assessing the Influence of Environmental Factors on Spatial Soil Erosion Risk based on the Certainty Coefficient Method
}

\author{
Jun Wang ${ }^{12^{*}}$, Qinghua Gong ${ }^{1,2}$, Yan $\mathrm{Yu}^{3}$ \\ ${ }^{1}$ Guangdong Open Laboratory of Geospatial Information Technology and Application, Guangzhou 510070, China \\ ${ }^{2}$ Guangzhou Institute of Geography, Guangzhou 510070, China \\ ${ }^{3}$ Construction and Water Services Bureau of Tianhe District, Guangzhou 510655, China
}

Received August 13, 2018

Accepted September 1, 2018

\begin{abstract}
Soil erosion is a very serious ecological problem and remains a highly contentious issue in Nanling National Nature Reserve, China. This paper assessed the spatial relationships between soil erosion risk and the environmental factors affecting soil erosion. Such research is significant for monitoring future land use/cover changes, including agricultural expansion and deterioration of forest resources. First, the soil erosion spatial distribution map was obtained by interpreting consecutive Landsat 8 satellite images, of which the interpreted result was validated via the intensive fieldwork. Then, from the perspective of topography, land cover, soil and rainfall, environmental factors that may influence the soil erosion risk were selected to quantitative test the relationships between soil erosion risk and the environmental factors using a certainty coefficient method. The results indicate that soil erosion is highly correlated to specific slope categories, elevation zones, distance to rivers, land use/cover type, stratum lithology, soil types and annual $24 \mathrm{~h}$ maximum rainfall. The occurrence probability of soil erosion is high in the area where the slope is larger than $40^{\circ}$. A remarkable variation in soil erosion loss displays in areas above $1300 \mathrm{~m}$ of elevation, and areas below $500 \mathrm{~m}$. The probability of soil erosion is the highest in the area within 100 meters of distance to rivers. Cultivated land, grassland and artificial surface land covers have the strongest soil erosion. The probability of soil erosion in the Cambrian and Carboniferous strata is the highest among the lithology categories. The red soil and scrubby-meadow soil have the strongest soil erosion. Soil erosion in the area of annual maximum $24 \mathrm{~h}$ rainfall between $110 \mathrm{~mm}$ and $120 \mathrm{~mm}$ is stronger than other area. The reported results provided viable information essential to control soil erosion, reduce soil loss, and achieve sustainable ecological development.
\end{abstract}

Keywords: soil erosion, environmental factor, CF value, soil conservation, Nanling National Nature Reserve

\section{Introduction}

Soil erosion is a natural geomorphic process, of which the extent and magnitude are controlled by various environmental variables, such as geology, topography, soil, climate, vegetation and human activities (Vrieling et al., 2006; Butt et al., 2010). Globally, total land area affected by soil erosion is 1094 Mha, of which 751 Mha is seriously deteriorated (Thomas et al., 2018). In the
Chinese context, considering the freeze-thaw erosion, soil erosion area reaches 4.92 million $\mathrm{km}^{2}$, accounting for $51.3 \%$ of the total land area. In South China, the soil erosion area is approximately $300,000 \mathrm{~km}^{2}$, which mainly distributed in the mountainous or hilly areas of red soil, where the soil erosion rate can reach 15,000 t $\mathrm{km}^{-2} \mathrm{yr}^{-1}$ (Zeng, 1992). Soil erosion is very harmful to soil fertility, agricultural productivity, reservoir capacity, water quality and human health (Posthumus et al., 2010;

\footnotetext{
* Corresponding author: E-mail: wangjun@gdas.ac.cn

Post address: No. 100, Middle of Xianlie Road, Yuexiu District, Guangzhou, Guangdong Province, China.
} 
Tamene et al., 2017). Therefore, it is necessary to define spatial distribution of soil erosion risk, its impact factors and areas with high soil erosion potential for soil and water conservation management.

Wide range of soil erosion models have been employed to predict soil erosion at varying scales (Lal, 2001; Lufafa et al., 2003; Kiunsi and Meadows, 2010). Of these models, the Universal Soil Loss Equation (USLE) and the revised model (RUSLE) have widely been used in conjunction with RS and GIS technology to predict the annual soil loss (Millward and Mersey, 1999; Merritt et al., 2003; Lu et al., 2004; Kouli, et al., 2009; Chen et al., 2011; Zhu, 2015; Ligonja and Shrestha, 2015; Panagos et al., 2015; Hao et al., 2017; Ostovar et al., 2017). For instance, Ganasri and Ramesh (2015) assessed total annual potential soil loss of about $473.339 \mathrm{t} \mathrm{h}^{-1} \mathrm{yr}^{-1}$ in Nethravathi Basin, India. Kayet et al. (2018) evaluated the greatest soil erosion of $440 \mathrm{t} \mathrm{ha}^{-1}$ $\mathrm{yr}^{-1}$ in hillslope mining areas using the RUSLE and SCS-CN models. Several attempts were done to explore the relationship between soil erosion and selected landforms (Jha et al., 2009; Kumar and Kishwaha, 2013; Ghosh et al., 2013), slope morphology (Lufafa et al., 2003) and landslides (Pradhan et al., 2012), but more consistent research was carried out recently to assess the relationship between specific environmental factors and soil loss in China, (Xu et al., 2008; Wu and Wang, 2011), Thailand (Bahadur, 2012) and South Africa (Manjoro et al., 2012) respectively.

Despite many researches of soil erosion have been reported, few works have been conducted in Guangdong Province, China, especially in the Nanling National Nature Reserve. Liu et al. (2005) analyzed temporal and spatial distribution of rainfall erosivity in Guangdong Province and found that the rainfall erosivity concentrated in the rainy season (April to September), which contributes $84.8 \%$ of the year. Zhu et al. (2007) studied the soil erodibility and its impact factors of Guangdong Province and found that the soil erodibility ranged from 0.116 to $0.415 \mathrm{t} \mathrm{h} \mathrm{MJ}^{-1} \mathrm{~mm}^{-1}$. Wang et al. (2016) analyzed the rainfall erosivity in the Lianjiang watershed in the Karst areas of northern Guangdong Province, China, by using data of daily precipitation from 1980 to 2013 at 35 meteorological stations. The result showed that the average annual rainfall erosivity was significantly higher in high mountain areas than in other places. Wang et al. (2018) assessed the soil erosion risk in Nanling National Nature Reserve, but did not study the influence of environmental factors on spatial soil erosion risk.

In the rugged, mountain tracts in the Nanling National Nature Reserve, soil erosion due to natural and/or man-made factors is a matter of grave concern. Because of the rugged and steeply sloping topography, heavy rainfall and increased overland flow caused by intensive human activities, this region is extremely vulnerable to various hillslope processes, such as soil erosion, land degradation, landslides and debris flows, which are seriously impact to local forest resources, water quality, biodiversity, and economy and social sustainability. Moreover, soil erosion risk and its influencing factors have never been identified so far in Nanling National Nature Reserve, China. Hence the objective of the present study is to evaluate the influence of environmental factors on the spatial soil erosion risk, and to present the relationships between soil erosion risk and the environmental factors recognized in the region. The study results are valuable for implementing future regional land management and conservation schemes to reduce soil loss.

\section{Study area}

\subsection{Basic description}

The Nanling National Nature Reserve (NNNR), located in northern part of Guangdong Province, South China, is selected as the study area (Fig. 1) covering an area of $583.68 \mathrm{~km}^{2}$ and between $24^{\circ} 37^{\prime} \mathrm{N}-25^{\circ} 00^{\prime} \mathrm{N}$ and $112^{\circ} 40^{\prime} \mathrm{E}-113^{\circ} 31^{\prime} \mathrm{E}$. The study area consists of five major sections: Dadingshan, Longtanjiao, Chengjia, Dadongshan and Ruyang.

Geologically, the region is located within the South China Block which is associated with two separate plates: the Cathaysian Block in the southeast and the Yangtze Block in the northwest, along with the closure of the paleo South China Ocean during the Neoproterozoic-Mesoproterozoic (900-850 Ma) period (Chen et al., 2015). Three main episodes of Mesozoic magmatic events have occurred: Triassic, Jurassic, and Cretaceous, and they are conventionally referred as the Indosinian, Early Yanshanian (EY), and Late Yanshanian (LY) stages of orogeny. Lithologically, 
granitic rocks are widespread in NNNR, especially Jurassic granitoids have the largest map area.

The study area is underlain by an E-W-trending mountain system. The terrain shows the topographical features of the northern and southern high, mountain valley alternately distributed. The highest peak is Shikengkong which is the first peak of Guangdong province and the elevation is $1902.3 \mathrm{~m}$. The lowest point is Longxikou which the elevation is $202.1 \mathrm{~m}$. The maximum and average slope in this area is $64.3^{\circ}$ and $19.5^{\circ}$, respectively.

The region has a subtropical monsoon climate. The multiyear average annual temperature is $17.7{ }^{\circ} \mathrm{C}$. The

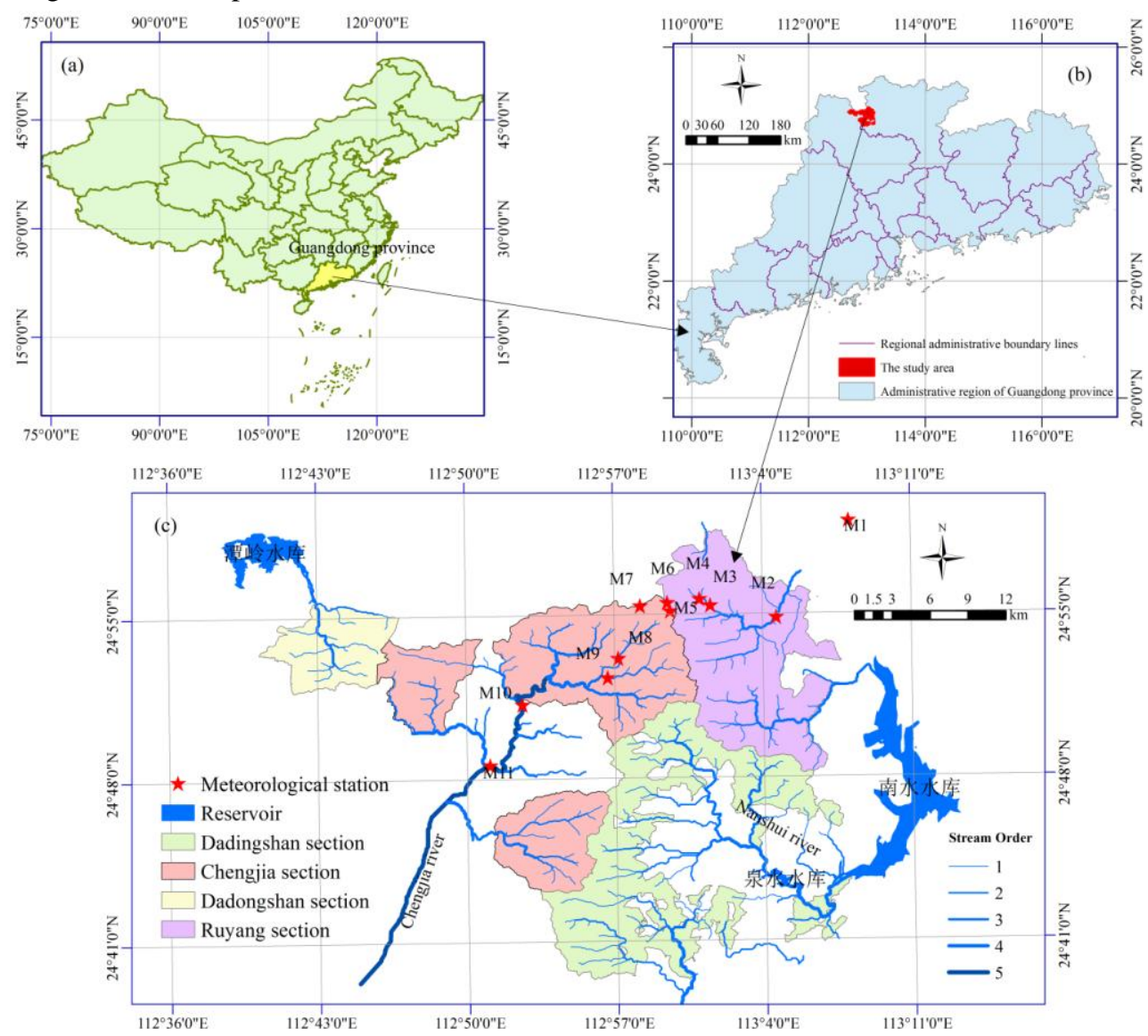

Fig.1. Location of the study area. (a) Inset map showing the location of Guangdong province in China. (b) Inset map showing the location of study area in Guangdong province. (c) Map of the study area with stream order and five major sections.

\subsection{Soil erosion types}

The joint influences of natural and human factors have caused severe soil erosion in the NNNR that has seriously affected local water safety and the ecological average annual precipitation ranges from 1500 to 2000 $\mathrm{mm}$, and around $80 \%$ of precipitation falls during March to October. The drainage networks are dendriform which can be roughly divided into five levels. From west to east, there are two major river watersheds: the Chengjia River and Nanshui River. The area comprises four main soil orders (red soil, redyellow soil, yellow soil, and scrubby-meadow soil), which present obvious vertical zonality. The vegetation ranges from subtropical evergreen broadleaved forest to alpine meadow; currently, the forest cover is $>90 \%$. 
types can be divided into four main categories: (a) rill erosion, widely distributed within the NNNR, especially within the scope of first-order drainage networks; (b) sheet erosion, widely distributed in high-elevation areas, especially developed around mountain ridge lines; (c) gully erosion, derived from rill erosion and widely distributed along gullies; and (d) human-induced erosion. To reduce soil loss within the NNNR and to protect its ecological environment, it is essential to determine the spatial distributions of soil erosion, identify the ecological risks posed by soil erosion, and understand the underlying influencing factors governing the soil erosion.
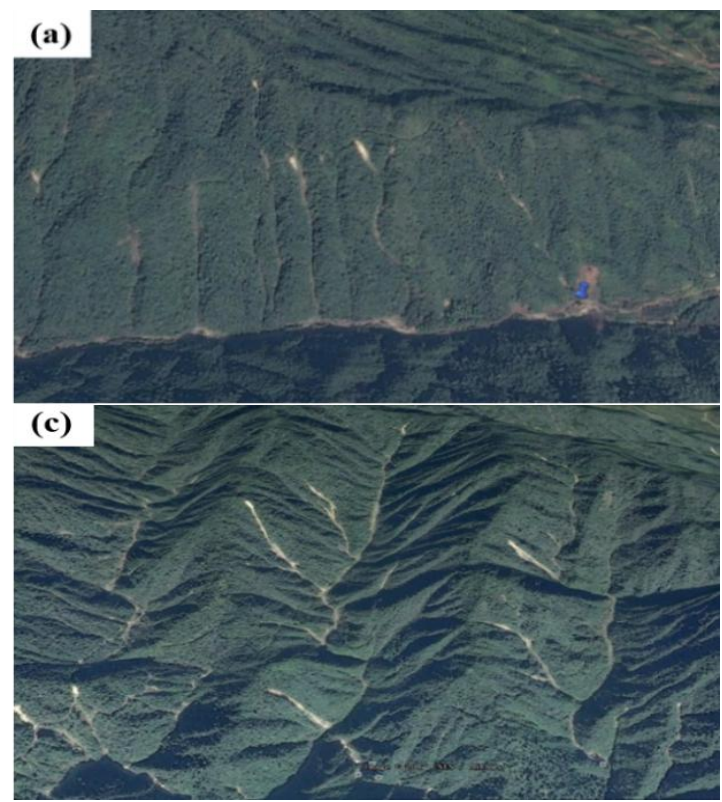

Fig.2. Examples of the soil erosion in the study area: (a) rill erosion, (b) sheet erosion (c) gully erosion and (d) human-induced .

\section{Materials and Methods}

In this study, the spatial distribution of soil erosion was interpreted first using the Landsat 8 satellite image with $30 \mathrm{~m}$ resolution. From the perspective of topography, land cover, soil and rainfall, environmental factors that may influence soil erosion risk were then selected to and environmental factors using a probability method. In this study, seven environmental factors were selected: slope, elevation, and distance to rivers, land covers, lithology, soil types, and annual maximum rainfall of 24 h. The GIS Tool Box was employed to generate each factor map, and to compute the soil erosion area in each factor categories. Finally, the tables of correlation quantitative test the relationships between soil erosion between soil erosion loss and the environment factors influencing soil erosion were calculated. The whole flowchart is shown in Fig. 3.

\subsection{Interpretation of soil erosion}

A Landsat 8 satellite image with $30 \mathrm{~m}$ resolution (No. LC81230432015106LGN00) from August 15, 2015, was used to interpret the spatial distributions of soil erosion in the NNNR, which was rectified and georeferenced to the WGS_1984_UTM_Zone_49N. We first interpreted the overall spatial distribution of soil erosion in the NNNR using the Support Vector Machine

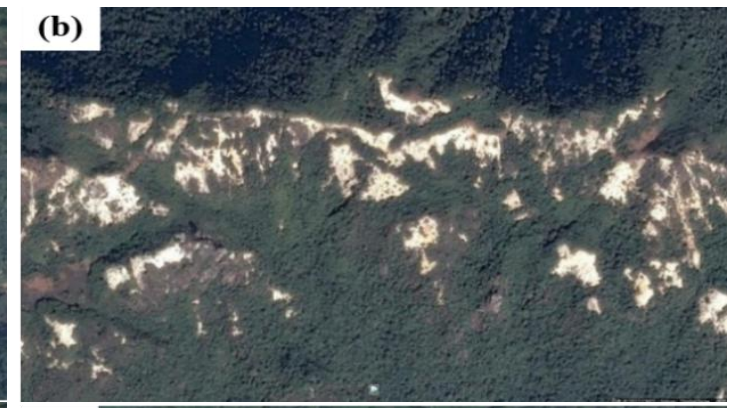

(d)

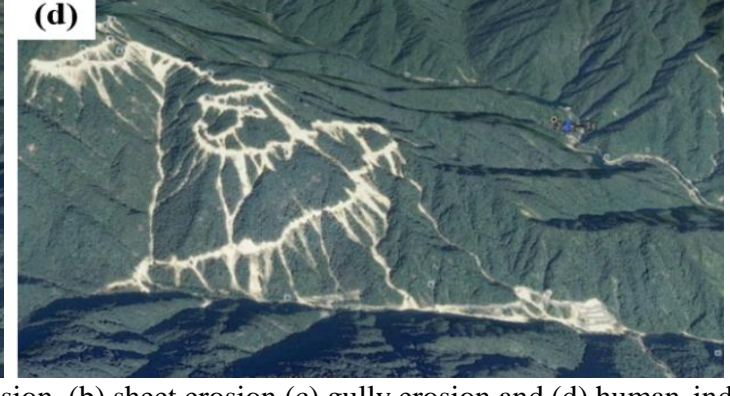

(b)
Supervised Classification of the ENVI 5.1 platform. Then, we validated the interpreted results via the intensive fieldwork. Fieldwork was undertaken several times in 2016, 2017, and 2018. Field investigations and sampling were conducted along the contour line mainly passing through the Ruyang section that could be reached on foot. The representative sample locations were identified and their geographic coordinates were recorded using a global positioning system receiver. These locations were later used as samples (in total 32 samples) with which to assess the image interpretation accuracy. For very important but inaccessible areas of erosion in the NNNR, we used an unmanned aerial vehicle to survey the soil erosion for the verification of the interpreted results. More than 4000 field pictures 
were taken, which were also used for visual verification of the results. These fieldwork data were used to validate the interpreted result of RS image.

\subsection{Analysis of the key influencing factors}

Here, a certainty coefficient method was used to analyze the influence of above factors in the spatial distribution of soil erosion (Heckerman, 1986; Wang et al., 2014):

$$
C F_{i}= \begin{cases}\frac{P_{a i}-P_{s}}{P_{a i}\left(1-P_{s}\right)} & \text { if } P_{a i} \geq P_{s} \\ \frac{P_{a i}-P_{S}}{P_{s}\left(1-P_{a i}\right)} & \text { if } P_{a i}<P_{s}\end{cases}
$$

where $C F_{i}$ is the certainty coefficient of the $i$-th data class, $P_{a i}$ is the conditional probability of soil erosion in data class $i, P_{s}$ is the a priori probability of soil erosion in the study area (constant), $i$ is the number of the data class in a factor, $i=1,2, \cdots, n$. The value of $P_{a i}$ can be calculated as:

$$
P_{a i}=\frac{a_{i}}{A_{i}}
$$

where $a_{i}$ is the area of soil erosion in data class $i$ and $A_{i}$ is the area of data class $i$. The value of $P_{s}$ can be calculated as:

$$
P_{S}=\frac{S_{i}}{S_{i}}
$$

where $s_{i}$ is the area of soil erosion in the study area, which is equal to the area of the interpreted results of soil erosion; here, $S_{i}$ is the area of the NNNR.

In ArcGIS software, each factor was first classified into several data classes. Then, the area of soil erosion in each data class and the area of each data class were calculated using zonal statistics methods. Finally, the values of $P_{s}, P_{a i}$, and $C F_{i}$ were calculated using Eqs. (3), (2), and (1), respectively. The calculated certainty coefficient $C F$ ranges from -1 to 1 . When the $C F$ value is close to 1 , the certainty of soil erosion is great and soil erosion is likely to occur. Conversely, when the $C F$ value is close to -1 , the certainty of soil erosion is low and soil erosion is less likely to occur. When the CF value is closer to zero, the priori probability and conditional probability are very close, and the certainty of the soil erosion is difficult to determine. According to the calculated $C F$ values of each data classes, the probability of soil erosion in each data classes can be obtained.

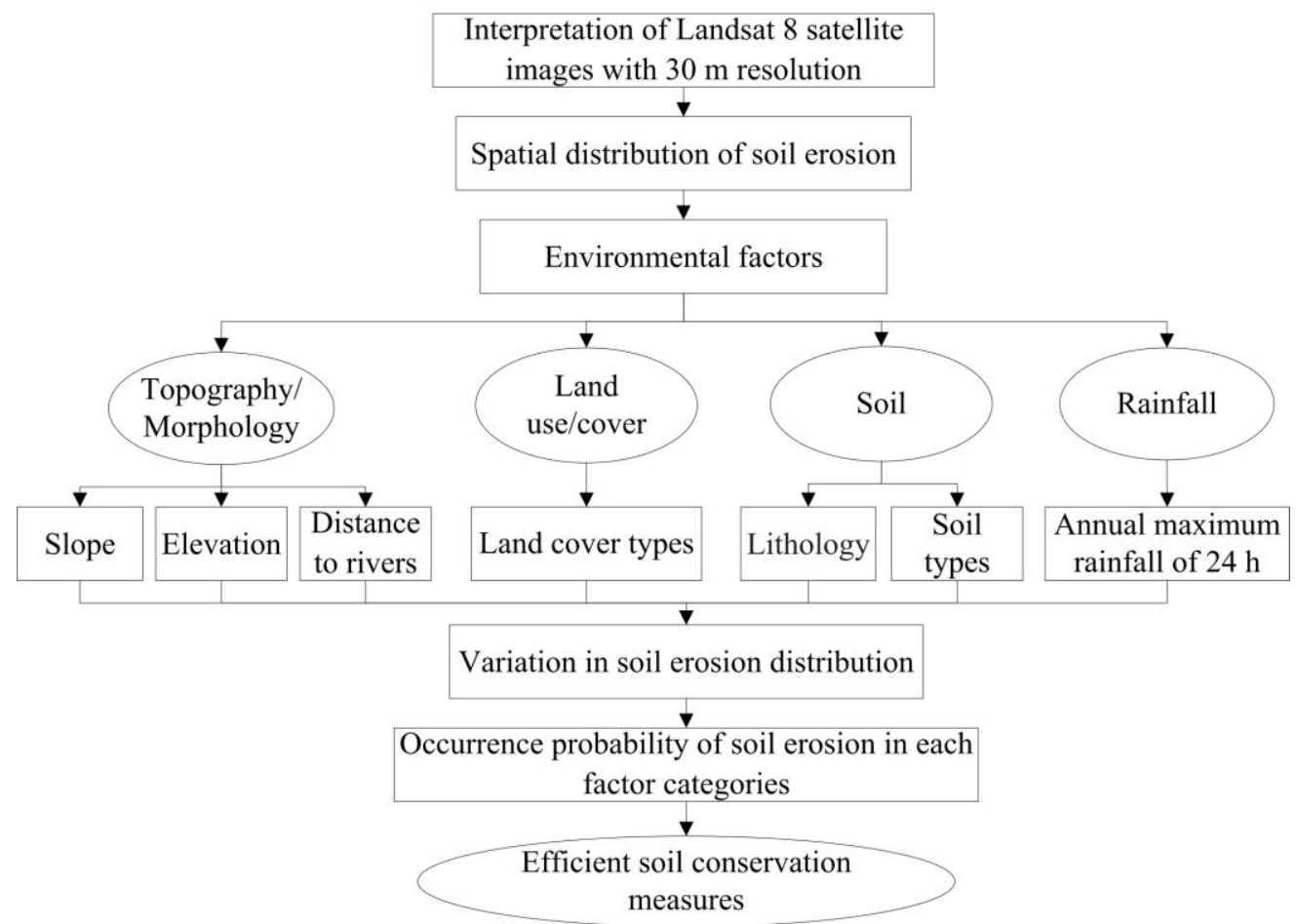

Fig. 3 The flowchart of this paper 


\section{Results}

\subsection{Interpretation results of soil erosion}

The interpreted results of soil erosion in the NNNR are shown in Fig. 4. The area of soil erosion is approximately $11.91 \mathrm{~km}^{2}$, accounting for $2.1 \%$ of the study area. The verification results show erosion areas larger than one cell size $(30 \mathrm{~m})$ agree well with the actual field situation; however, erosion areas smaller than one cell size are comparatively inconsistent. Nevertheless, the overall accuracy of the 32 sampling sites was $87.75 \%$, indicating that errors introduced by the interpretation are acceptable.

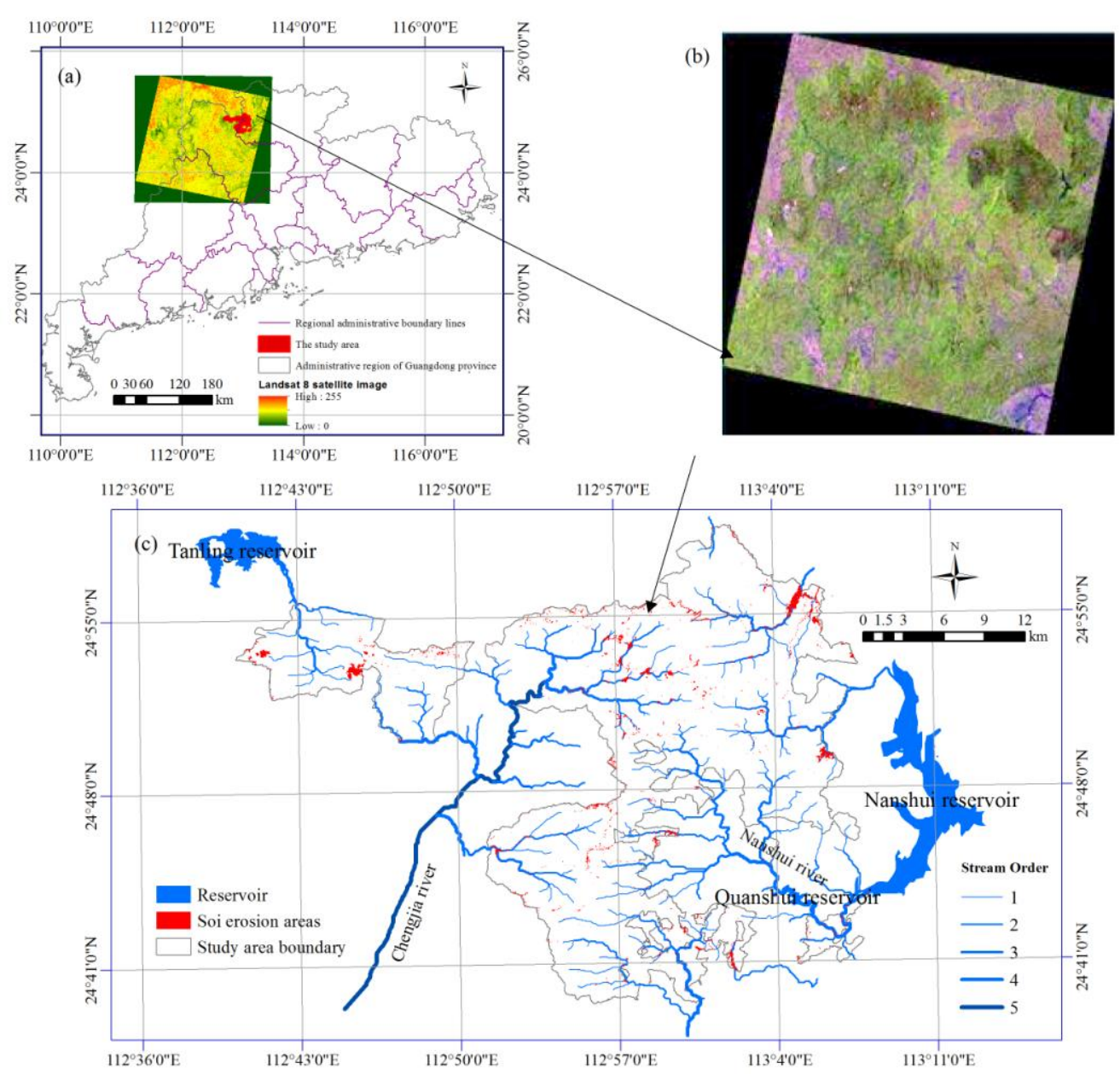

Fig. 4 Interpretation of soil erosion in the study area from Landsat 8 satellite image. (a) Inset map showing the location of Landsat 8 satellite image in Guangdong province. (b) The Landsat 8 satellite image of the study area. (c) The interpreted result of the soil erosion area.

\subsection{Relationship between soil erosion and environmental factors}

\subsubsection{Slope}

The slope of NNNR can be divided into six categories, seen in Fig. 5. The area of each slope category and the area of soil erosion in each slope category can be calculated using the zonal statistics method in ArcGIS 10.1. The values of $P_{a}$ and $P_{s}$ can be computed based on Eq. (2) and Eq. (3). Finally, according to Eq. (1), the occurrence probability of soil erosion in each slope category can be obtained (Table 1). 
As shown in Table 1, the occurrence probability of soil erosion is high in the area where the slope is larger than $40^{\circ}$. The CF value is above 0.51 . Especially, when the slope in larger than $50^{\circ}$, the $\mathrm{CF}$ value reaches 0.73 and occurrence probability of soil erosion is the highest. It is indicated that the occurrence probability of soil erosion increases with an increase in the slope angle.

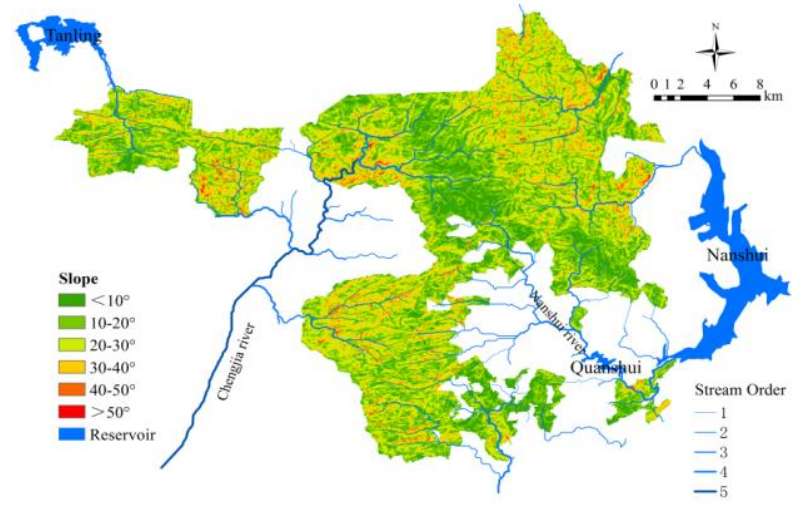

Fig. 5 Slope categories in NNNR

Table 1 Spatial variation of soil erosion with slope categories

\begin{tabular}{cccccc}
\hline $\begin{array}{c}\text { Catego } \\
\text { ries } \\
\left({ }^{\circ}\right)\end{array}$ & $\begin{array}{c}\text { Area } \\
(\text { ha })\end{array}$ & $\begin{array}{c}\text { Soil } \\
\text { erosion } \\
\text { area (ha) }\end{array}$ & $P_{a}$ & $P_{s}$ & CF \\
\hline$<10$ & 10745.55 & 213.96 & 0.0199 & 0.0205 & -0.03 \\
$10-20$ & 20186.01 & 411.01 & 0.0204 & 0.0205 & -0.01 \\
$20-30$ & 18166.86 & 348.27 & 0.0192 & 0.0205 & -0.07 \\
$30-40$ & 7759.53 & 149.93 & 0.0193 & 0.0205 & -0.06 \\
$40-50$ & 1124.01 & 45.71 & 0.0407 & 0.0205 & 0.51 \\
$>50$ & 385.84 & 28.03 & 0.0726 & 0.0205 & 0.73 \\
\hline
\end{tabular}

\subsubsection{Elevation}

The elevation of NNNR can be divided into six categories according to DEM with $30 \mathrm{~m}$ resolution (Fig. $6)$. The area of each elevation category and the area of soil erosion in each elevation category can be calculated using the zonal statistics method in ArcGIS 10.1. The values of $P_{a}$ and $P_{s}$ can be computed based on Eq. (2) and Eq. (3). Finally, according to Eq. (1), the occurrence probability of soil erosion in each elevation category can be obtained (Table 2).

From Table 2, it is found that soil erosion is very serious in areas with elevation above $1300 \mathrm{~m}$ and elevation below $700 \mathrm{~m}$, of which the $\mathrm{CF}$ value is larger than 0.35 . The elevation smaller than $400 \mathrm{~m}$

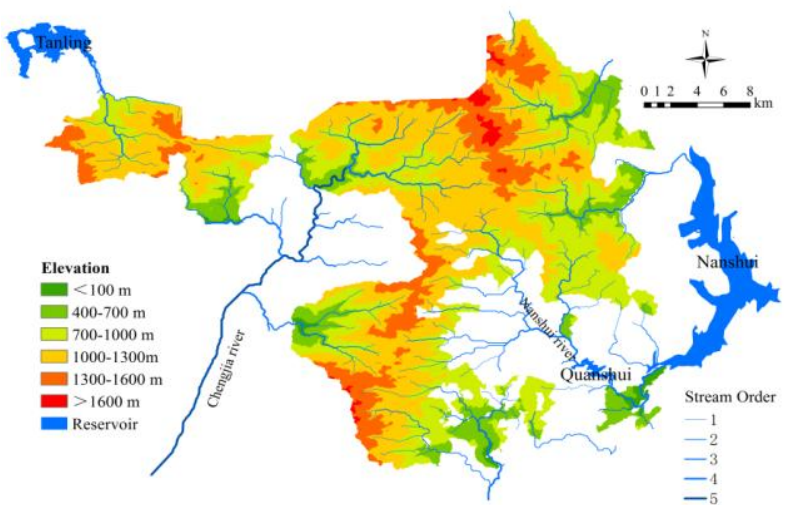

Fig. 6 Elevation categories in NNNR

Table 2 Spatial variation of soil erosion with elevation

\begin{tabular}{cccccc}
\multicolumn{7}{c}{ categories } \\
$\begin{array}{c}\text { Categories } \\
(\mathrm{m})\end{array}$ & $\begin{array}{c}\text { Area } \\
(\text { ha })\end{array}$ & $\begin{array}{c}\text { Soil } \\
\text { erosion } \\
\text { area (ha) }\end{array}$ & $P_{a}$ & $P_{s}$ & $\mathrm{CF}$ \\
\hline$<400$ & 1022.5 & 78.48 & 0.0768 & 0.0205 & 0.75 \\
$400-700$ & 6722.46 & 313.92 & 0.0467 & 0.0205 & 0.57 \\
$700-1000$ & 19180.4 & 303.39 & 0.0158 & 0.0205 & -0.23 \\
$1000-1300$ & 23037.0 & 235.17 & 0.0102 & 0.0205 & -0.51 \\
$1300-1600$ & 7847.28 & 246.15 & 0.0314 & 0.0205 & 0.35 \\
$>1600$ & 558.18 & 19.8 & 0.0355 & 0.0205 & 0.43 \\
\hline
\end{tabular}

has the highest $\mathrm{CF}$ value and worst soil erosion, this may be because this range has intense human activities inducing the soil erosion.

\subsubsection{Distance to rivers}

Distance to rivers is an extremely significant factor affecting formation of soil erosion, as well as human activity intensity. In this paper, the distance to rivers data is derived from drainage network vector data based on the DEM with $30 \mathrm{~m}$ resolution. The distance to rivers of NNNR can be divided into six categories (Fig. 7). The area of each category and the area of soil erosion in each category can be calculated using the zonal statistics method in ArcGIS 10.1. The values of $P_{a}$ and $P_{s}$ can be computed based on Eq. (2) and Eq. (3). Finally, according to Eq. (1), the occurrence probability of soil erosion in each category can be obtained (Table 3 ).

As shown in Table 1, the probability of soil erosion is high in the area within 100 meters of distance to rivers, and the $\mathrm{CF}$ value reaches 0.55 . The closer the distance to rivers, the stronger the power of water and human activity, and the more severe soil erosion. 


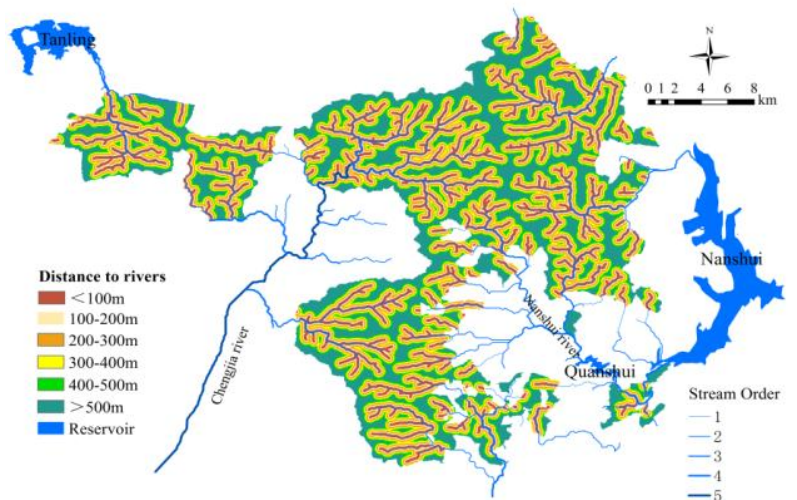

Fig. 7 Distance to rivers categories in NNNR

Table 3 Spatial variation of soil erosion with distance to rivers

\begin{tabular}{cccccc}
\multicolumn{7}{c}{ categories } \\
\hline $\begin{array}{c}\text { Categories } \\
(\mathrm{m})\end{array}$ & $\begin{array}{c}\text { Area } \\
(\text { ha })\end{array}$ & $\begin{array}{c}\text { Soil } \\
\text { erosion } \\
\text { area (ha) }\end{array}$ & $P_{a}$ & $P_{s}$ & CF \\
\hline$<100$ & 9742.86 & 434.25 & 0.0446 & 0.0205 & 0.55 \\
$100-200$ & 9160.74 & 162.27 & 0.0177 & 0.0205 & -0.14 \\
$200-300$ & 8962.74 & 104.13 & 0.0116 & 0.0205 & -0.44 \\
$300-400$ & 8135.28 & 83.79 & 0.0103 & 0.0205 & -0.5 \\
$400-500$ & 7007.85 & 81.63 & 0.0116 & 0.0205 & -0.44 \\
$>500$ & 15358.3 & 330.84 & 0.0215 & 0.0205 & 0.01 \\
\hline
\end{tabular}

\subsubsection{Land covers}

According to land covers in NNNR, the land covers can be divided into five categories: cultivated land, forest, grassland, waterbodies, and artificial surface (Fig .8). The area of each category and the area of soil erosion in each category can be calculated using the zonal statistics method in ArcGIS 10.1. The values of $P_{a}$ and $P_{s}$ can be computed based on Eq. (2) and Eq. (3). Finally, according to Eq. (1), the occurrence probability of soil erosion in each category can be obtained (Table 4).

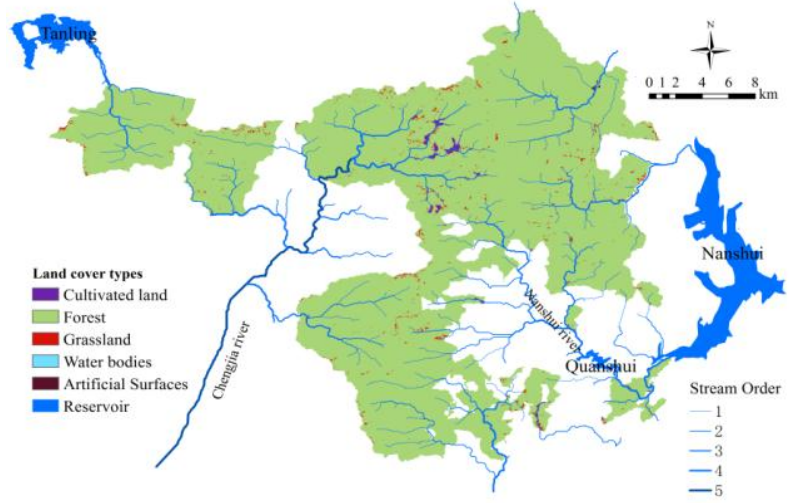

Fig. 8 Land cover categories in NNNR
Table 4 Spatial variation of soil erosion with land cover

\begin{tabular}{cccccc}
\multicolumn{7}{c}{ categories } \\
\hline $\begin{array}{c}\text { Categorie } \\
\mathrm{s}\end{array}$ & $\begin{array}{c}\text { Area } \\
\text { ( ha })\end{array}$ & $\begin{array}{c}\text { Soil } \\
\text { erosion } \\
\text { area (ha) }\end{array}$ & $P_{a}$ & $P_{s}$ & CF \\
\hline Cultivated & 195.3 & 74.61 & 0.382 & 0.0205 & 0.97 \\
land & 57429.8 & 960.84 & 0.0167 & 0.0205 & -0.19 \\
$\begin{array}{c}\text { Forest } \\
\text { Grassland } \\
\text { Water } \\
\text { bodies }\end{array}$ & 723.51 & 146.25 & 0.2021 & 0.0205 & 0.92 \\
$\begin{array}{c}\text { Artificial } \\
\text { Surface }\end{array}$ & 15.39 & 0.45 & 0.119 & 0.0205 & 0.85 \\
\hline
\end{tabular}

From Table 4, it is found that the soil erosion of land cover types with Cultivated land, Grassland, Artificial Surface are the strongest, with CF values above 0.85 .

\subsubsection{Lithology}

The materials used here mainly are geological data including 1:200,000 print and digital geological map. According to the geological data, the NNNR has five categories lithology, seen in Fig. 9. The area of each lithology category and the area of soil erosion in each lithology category can be calculated using the zonal statistics method in ArcGIS 10.1. The values of $P_{a}$ and $P_{s}$ can be computed based on Eq. (2) and Eq. (3). Finally, according to Eq. (1), the occurrence probability of soil erosion in each lithology category can be obtained (Table 5).

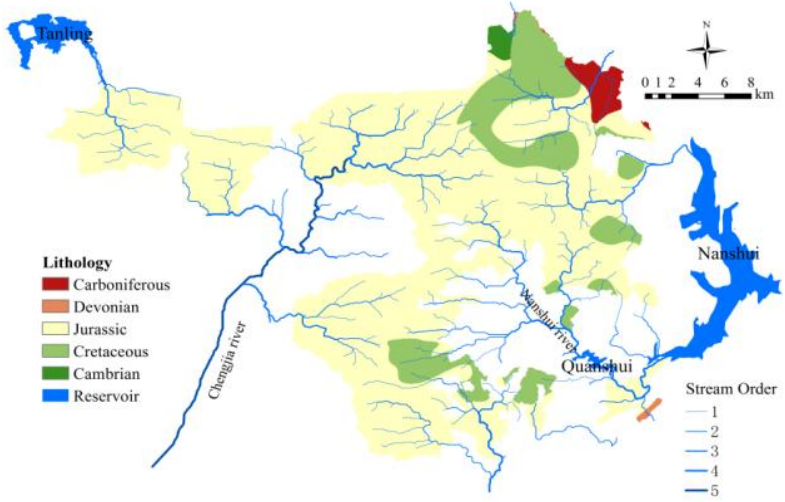

Fig. 9 Land cover categories in NNNR

The probability of soil erosion in the Cambrian and Carboniferous strata is the highest among the lithology categories, with $\mathrm{CF}$ values reaching 0.82 and 0.88 (Table 5), respectively. It is indicating that the soft rock such as mudstone, slate, shale and coal-bearing strata has the serious soil erosion. 
Table 5 Spatial variation of soil erosion with land cover

\begin{tabular}{cccccc}
\multicolumn{6}{c}{ categories } \\
\hline $\begin{array}{c}\text { Categorie } \\
\text { s }\end{array}$ & $\begin{array}{c}\text { Area } \\
\text { ( ha })\end{array}$ & $\begin{array}{c}\text { Soil } \\
\text { erosion } \\
\text { area (ha) }\end{array}$ & $P_{a}$ & $P_{s}$ & CF \\
\hline Cretaceou & 8951.01 & 155.79 & 0.0174 & 0.0205 & -0.15 \\
s & & 816.48 & 0.0171 & 0.0205 & -0.17 \\
Jurassic & 47663.5 & 0.15 & 0.0205 & 0.88 \\
Carbonife & 1188.88 & 178.38 & 0.0213 & 0.0205 & 0.04 \\
rous & & 3.24 & 0.021043 & 0.0205 & 0.82 \\
Devonian & 151.84 & 43.02 & 0.104 \\
Cambrian & 412.49 & & & & \\
\hline
\end{tabular}

\subsubsection{Soil types}

According to the soil types in NNNR, the soil types can be divided into four categories: red soil, red-yellow soil, yellow soil, and scrubby-meadow soil (Fig. 10). The area of each soil type category and the area of soil erosion in each soil type category can be calculated using the zonal statistics method in ArcGIS 10.1. The values of $P_{a}$ and $P_{s}$ can be computed based on Eq. (2) and Eq. (3). Finally, according to Eq. (1), the occurrence probability of soil erosion in each soil type category can be obtained (Table 6).

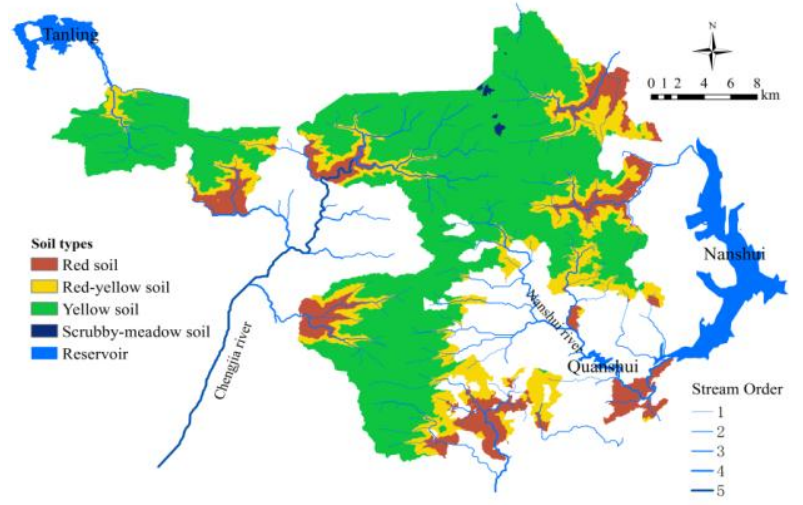

Fig.10 Soil type categories in NNNR

Table 6 Spatial variation of soil erosion with soil types

\begin{tabular}{cccccc}
\multicolumn{7}{c}{ categories } \\
\hline Categories & $\begin{array}{c}\text { Area } \\
\text { ( ha })\end{array}$ & $\begin{array}{c}\text { Soil } \\
\text { erosion } \\
\text { area (ha) }\end{array}$ & $P_{a}$ & $P_{s}$ & CF \\
\hline Red soil & 7438.41 & 360.9 & 0.0485 & 0.0205 & 0.59 \\
$\begin{array}{c}\text { Red-yellow } \\
\text { soil }\end{array}$ & 11191.32 & 207.54 & 0.0185 & 0.0205 & -0.1 \\
$\begin{array}{c}\text { Yellow soil } \\
\text { Scrubby- } \\
\text { meadow } \\
\text { soil }\end{array}$ & 39616.57 & 622.44 & 0.0157 & 0.0205 & -0.24 \\
\hline
\end{tabular}

As shown in Table 6, the yellow soil has the largest distribution area with 39616.57 ha. The scrubbymeadow soil has the least distribution area with 121.5 ha. However, the red soil and scrubby-meadow soil have the strongest soil erosion with $\mathrm{CF}$ values of 0.59 and 0.60 , respectively.

\subsubsection{Annual maximum rainfall of $24 \mathrm{~h}$}

The annual maximum rainfall of $24 \mathrm{~h}$ in NNNR can be obtained from the Guangdong Hydrology Record Handbook (Guangdong Provincial Hydrographic Bureau 1991), which can be divided into four categories, seen in Fig. 11. The area of each category and the area of soil erosion in each category can be calculated using the zonal statistics method in ArcGIS 10.1. The values of $P_{a}$ and $P_{s}$ can be computed based on Eq. (2) and Eq. (3). Finally, according to Eq. (1), the occurrence probability of soil erosion in each category can be obtained (Table 7).

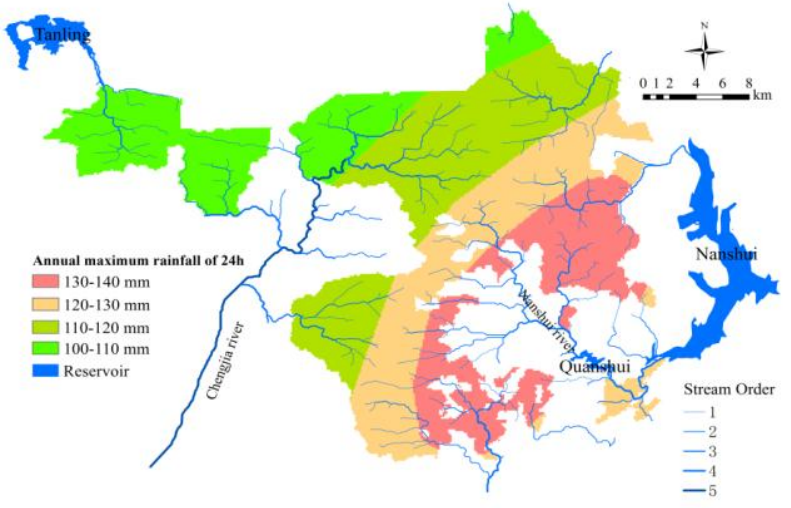

Fig.11 Annual maximum rainfall categories in NNNR

Table 7 Spatial variation of soil erosion with annual maximum rainfall categories

\begin{tabular}{cccccc}
\hline $\begin{array}{c}\text { Categories( } \\
\text { mm) }\end{array}$ & $\begin{array}{c}\text { Area } \\
\text { ( ha })\end{array}$ & $\begin{array}{c}\text { Soil } \\
\text { erosion } \\
\text { area (ha) }\end{array}$ & $P_{a}$ & $P_{s}$ & CF \\
\hline$<110$ & 13992.85 & 263.79 & 0.0189 & 0.0205 & -0.08 \\
$110-120$ & 17619.93 & 518.49 & 0.0294 & 0.0205 & 0.31 \\
$120-130$ & 15014.97 & 201.78 & 0.0134 & 0.0205 & -0.35 \\
$130-140$ & 11740.05 & 212.85 & 0.0181 & 0.0205 & -0.12 \\
\hline
\end{tabular}

From Table 7, it is found that soil erosion in the area of annual maximum $24 \mathrm{~h}$ rainfall between $110 \mathrm{~mm}$ and $120 \mathrm{~mm}$ is stronger than other area, and the CF value is 0.31 . There is no positive correlation between soil erosion and rainfall, this may be the soil erosion in this region are extremely complex due to the steep slope, complicated topography and intensive anthropogenic 
activity. In other words, the rainfall is not a control factor of soil erosion in NNNR comparing with the complicated topography and intensive anthropogenic activity.

\section{CONCLUSIONS}

This paper quantitatively analyzed the spatial relationships between soil erosion risk and the environmental factors affecting soil erosion in Nanling National Nature Reserve, China. Seven factors that may influence the soil erosion risk were selected from the perspective of topography, land cover, soil and rainfall. It is found that soil erosion in NNNR is highly correlated to specific factor categories. The occurrence probability of soil erosion is very high in the area where the slope is larger than $40^{\circ}$, elevation below $700 \mathrm{~m}$, distance to rivers within $100 \mathrm{~m}$, and the maximum $24 \mathrm{~h}$ rainfall between $110 \mathrm{~mm}$ and $120 \mathrm{~mm}$. The soil erosion is also susceptible in the soil type of red and scrubbymeadow, land cover types of cultivated land and Grassland, and lithology categories of the Cambrian and Carboniferous strata.

The results revealed which segments or categories of environmental factors had the worst soil erosion risk, and what measures we should take to restrict this development in certain areas. The GIS database and maps of environmental factors generated in this research provide valuable planning aids for managers to help them decrease soil erosion risk. The database created during this study can be interrogated to identify land areas currently under intensive human activity with a high or very high ranking for the risk of potential soil erosion, which are should be targeted for particular protection.

\section{Acknowledgement}

This research was supported by the Natural Science Foundation of Guangdong Province (2018A030310469), the Water Resource Science and Technology Innovation Program of Guangdong Province (2016-15), GDAS' Project of Science and Technology Development (2017GDASCX-0803; 2017GDASCX-0101), and the Science and Technology Project of Guangzhou City (201804010126; 201803030025).

\section{References}

1. Bahadur, K. C. (2012). Spatio-temporal patterns of agricultural expansion and its effect on watershed degradation: a case study from the mountains of Nepal. Environmental Earth Science, 65(7): 2063-2077. doi: 10.1007/s12665-011-1186-6.

2. Butt, M. J., Waqas, A., \& Mahmood, R. (2010). The combined effect of vegetation and soil erosion in the water resource management. Water Resources Management, 24(13): 3701-3714. doi: 10.1007/s11269010-9627-7.

3. Chen, T., Niu, R., \& Li, P. et al. (2011). Regional soil erosion risk mapping using RUSLE, GIS, and remote sensing: a case study in Miyun watershed, North China. Environmental Earth Sciences, 63(3): 533-541. doi: 10.1007/s12665-010-0715-z.

4. Chen, G. X., Liu, T. Y., \& Sun J. S. et al. (2015). Gravity method for investigating the geological structures associated with W-Sn polymetallic deposits in the Nanling Range, China. Journal of Applied Geophysics, 120: 14-25. doi: 10.1016/j.jappgeo.2015.06.001.

5. Ganasri, B.P., \& Ramesh, H. (2015). Assessment of soil erosion by RUSLE model using remote sensing and GIS a case study of Nethravathi Basin. Geoscience Frontiers, 7(6): 953-961. doi: 10.1016/j.gsf.2015.10.007.

6. Ghosh, K., De, S. K., \& Bandyopadhyay, S. et al. (2013). Assessment of soil loss of the Dhalai River Basin, Tripura, India using USLE. International Journal of Geosciences, 4(1): 11- 23. doi: 10.4236/ijg.2013.41002.

7. Guangdong Provincial Hydrographic Bureau. (1991) Guangdong Province Rainstorm Runoff Chart User Manual.

8. Hao, C., Oguchi, T., \& Pan, W. U. (2017). Assessment for soil loss by using a scheme of alterative sub-models based on the RUSLE in a Karst Basin of Southwest China. Journal of Integrative Agriculture, 16(2): 377-388. doi: 10.1016/S2095-3119(16)61507-1.

9. Heckerman, D. (1986). Probabilistic Interpretations for Mycin's Certainty Factors. Machine Intelligence \& Pattern Recognition 4: 167-196. doi: 10.1016/B978-0444-70058-2.50017-6.

10. Jha, P., Nitant, H. C., \& Mandal, D. (2009) Establishing permissible erosion rates for various landforms in Delhi State, India. Land Degradation \& Development, 20(1): 92-100. doi: 10.1002/ldr.886.

11. Kayet, N., Pathak, K., \& Chakrabarty, A. (2018). Evaluation of soil loss estimation using the RUSLE model and SCS-CN method in hillslope mining areas. International Soil \& Water Conservation Research, 6(1):31-42. doi: 10.1016/j.iswcr.2017.11.002.

12. Kiunsi, R. B., \& Meadows, M. E. (2010). Assessing land degradation in the Monduli District, northern Tanzania. Land Degradation \& Development, 17(5): 509-525. doi: 10.1002/ldr.733. 
13. Kouli, M., Soupios, P., \& Vallianatos, F. (2009). Soil erosion prediction using the revisedMuniversal soil loss equation (RUSLE) in a GIS framework, Chania, Northwestern Crete, Greece. Environmental Geology, 57(3): 483-497. doi: 10.1007/s00254-008-1318-9.

14. Kumar, S., \& Kushwaha, S. (2013). Modelling soil erosion risk based on RUSLE-3D using GIS in a Shivalik sub-watershed, Journal of Earth System Science, 122(2): 389-398. doi: 10.1007/s12040-013-0276-0.

15. Lal, R. (2001). Soil degradation by erosion. Land Degradation \& Development, 12(6): 519-539. doi: 10.1002/ldr.472.

16. Ligonja, P. J., Shrestha, R. P. (2015). Soil Erosion Assessment in Kondoa Eroded Area in Tanzania using Universal Soil Loss Equation, Geographic Information Systems and Socioeconomic Approach. Land Degradation \& Development, 26(4): 367-379. doi: 10.1002/ldr.2215.

17. Liu, P., Wu, Z. F., \& Kuang, Y. Q. et al. (2005). Analysis of rainfall erosivity on the daily precipitation in Guangdong province. Journal of Tropical Meteorology, 21(5): 555-561. (in Chinese)

18. Lufafa, A., Tenywa, M. M., \& Isabirye, M. et al. (2003). Prediction of soil erosion in a Lake Victoria basin catchment using a GIS-based Universal Soil Loss model. Agricultural Systems, 76(3): 883-894. doi: 10.1016/S0308-521X(02)00012-4.

19. Lu, D., Li, G., \& Valladares, G. S. et al. (2004). Mapping soil erosion risk in Rondônia, Brazilian Amazonia: using RUSLE, remote sensing and GIS. Land Degradation \& Development, 15(5): 499-512. doi: 10.1002/ldr.634.

20. Manjoro, M., Kakembo, V., \& Rowntree, K. M. (2012). Trends in soil erosion and woody shrub encroachment in Ngqushwa District, Eastern Cape Province, South Africa. Environmental Management, 49(3): 570-579. doi: 10.1007/s00267-012-9810-0.

21. Merritt, W. S., Letcher, R. A., \& Jakeman, A. J. (2003). A review of erosion and sediment transport models. Environmental Modelling \& Software, 18(8): 761-799. doi: 10.1016/S1364-8152(03)00078-1

22. Millward, A. A., \& Mersey, J. E. (1999). Adapting the RUSLE to model soil erosion potential in a mountainous tropical watershed. Catena, 38(2): 109-129. doi: 10.1016/S0341-8162(99)00067-3.

23. Ostovari, Y., Ghorbani-Dashtaki, S., \& Bahrami, H.A. et al. (2017). Soil loss estimation using RUSLE model, GIS and remote sensing techniques: A case study from the Dembecha Watershed, Northwestern Ethiopia. Geoderma Regional, 11: 28-36. doi: 10.1016/j.geodrs.2017.06.003.

24. Panagos, P., Borrelli, P., \& Poesen, J. et al. (2015). The new assessment of soil loss by water erosion in Europe. Environmental Science \& Policy, 54(): 438-447. doi: 10.1016/j.envsci.2015.08.012.

25. Posthumus, H., Deeks, L. K., \& Fenn, I. et al. (2010). Soil conservation in two English catchments: Linking soil management with policies. Land Degradation \& Development, 22(3): 97-110. doi: 10.1002/ldr.987.

26. Pradhan, B., Chaudhari, A., \& Adinarayana, J. et al. (2012). Soil erosion assessment and its correlation with landslide events using remote sensing data and GIS: a case study at Penang Island, Malaysia. Environmental Monitoring Assessment, 184(2): 715-727. doi 10.1007/s10661-011-1996-8

27. Tamene, L., Adimassu, Z., \& Ellison, J. et al. (2017). Mapping soil erosion hotspots and assessing the potential impacts of land management practices in the highlands of Ethiopia. Geomorphology, 292: 153-163. doi: 10.1016/j.geomorph.2017.04.038.

28. Thomas, J., Joseph, S., \& Thrivikramji, K. P. (2018). Assessment of soil erosion in a tropical mountain river basin of the southern Western Ghats, India using RUSLE and GIS. Geoscience Frontiers, 9(3): 893-906. doi: 10.1016/j.gsf.2017.05.011.

29. Vrieling, A., Sterk, G., \& Vigiak, O. (2010). Spatial evaluation of soil erosion risk in the West Usambara Mountains, Tanzania. Land Degradation \& Development, 17 (3): 301-319. doi: 10.1002/ldr.711.

30. Wang, J., Yan, Y., \& Yang, S. et al. (2014). A modified certainty coefficient method (M-CF) for debris flow susceptibility assessment: A case study for the Wenchuan earthquake meizoseismal area. Journal of Mountain Science, 11(5): 1286-1297. doi: 10.1007/s11629-0132781-7.

31. Wang, J., Zhou, P., Gong, Q. H. et al. (2018). Study on the Soil Erosion Sensitivity in the Nanling Mountains, Guangdong, Using the RUSLE Model. Tropical Geography, 38(3): 347-355. (in Chinese)

32. Wang, M., Zhang, X., \& Wang, X. Z. et al. (2016). Rainfall Erosivity in the Lianjiang Watershed in Karst Areas of Northern Guangdong, China. Tropical Geography, 36: 495-502. (in Chinese)

33. Wu, X., \& Wang, X. (2011). Spatial influence of geographical factors on soil erosion in Fuyang County, China. Procedia Environmental Sciences, 10(1): 21282133. doi: 10.1016/j.proenv.2011.09.333.

34. Xu, Y. Q., Shao, S. M., \& Kong X. B. et al. (2008). Adapting the RUSLE and GIS to model soil erosion risk in a mountain karst watershed, Guizhou Province, China, Environmental Monitoring Assessment, 141(1-3): 275286. doi: 10.1007/s10661-007-9894-9.

35. Zhu, M. (2015). Soil erosion assessment using USLE in the GIS environment: a case study in the Danjiangkou Reservoir Region, China. Environmental Earth Sciences, 73(12): 7899-7908. doi: 10.1007/s12665-014-3947-5.

36. Zhu, L. A., Li, D. Q., \& Wei, X. G. et al (2007). The current situation of soil erodibility $(\mathrm{K})$ value and its impact factors in Guangdong Province. Subtropical Soil and Water Conservation, 19: 4-7. (in Chinese)

37. Zeng, Z. X. (1992). Soil erosion on the red soil regions in South China. Pearl River, 6: 15-20. (in Chinese) 